\title{
Distribution of Cassava Bacterial Blight and Reaction of Selected Cassava Genotypes to the Disease in Kenya
}

\author{
Hilda M. Odongo Douglas W. Miano* William M. Muiru \\ Agnes W. Mwang'ombe John W. Kimenju \\ Department of Plant Science and Crop Protection, University of Nairobi, P.O. Box 29053-0100, Nairobi, Kenya
}

\begin{abstract}
Cassava bacterial blight (CBB) disease is an important bacterial disease of cassava. A study was carried out to determine the distribution of CBB in Kenya and to evaluate selected cassava genotypes for reaction to the disease. A survey was conducted in all the cassava growing regions within the country where cassava leaves showing symptoms of CBB were collected and isolated for biochemical characterization and PCR detection of the causal agent. The isolates were then used to determine the reaction of seven cassava genotypes to the disease. The disease was present in 17 out of the 21 counties surveyed. The bacteria extracted from the leaf samples conformed to all the biochemical and physiological tests specific to Xanthomonas axonopodis pv manihotis and to xanthomonads in general. Polymerase chain reaction amplified the expected 500 base pairs fragment. Disease prevalence was highest in Kwale County at $100 \%$ Kilifi County recorded the highest incidence at $64 \%$. All the genotypes evaluated in the greenhouse had area under disease progress curve (AUDPC) values higher than 52 which grouped them as susceptible. The study confirms the wide distribution of CBB in Kenya and the presence of the disease in the coast region, which was previously considered $\mathrm{CBB}$ free. The study also shows that some of the cassava genotypes being targeted for improvement by other projects are susceptible to the disease, and therefore the need consider resistance to $\mathrm{CBB}$ in developing improved cassava genotypes.
\end{abstract}

Keywords: Cassava bacterial blight, Distribution, Resistance

DOI: $10.7176 / \mathrm{JNSR} / 9-4-05$

\section{Introduction}

Cassava (Manihot esculenta) is ranked the fourth most important food crop in the world after rice, wheat and maize, and is an important source of carbohydrates for over 500 million people in the tropics (Rowan et al. 2010). Cassava is also used as a carbohydrate source in animal feed and a raw material in various industrial products (Tonukari 2004). Cassava production in Africa is hindered by various biotic and abiotic factors including bacterial blight (CBB) disease caused by Xanthomonas axonopodis pv. manihotis (Xam) (Trujilo et al. 2014).

Methods of identifying and detecting Xam have for a long time been dependent on isolating the bacteria, carrying out biochemical and serological tests such as enzyme linked immunosorbent assays (ELISA) (Ojeda and Verdier, 2000). However, these methods are not very accurate as they are not entirely specific because of cross reactions (Ojeda \& Verdier 2000). Molecular techniques such as polymerase chain reaction (PCR) are highly effective in the detection of plant pathogenic bacteria such as Xanthomonas axonopodis pv. phaseoli and Xanthomonas axonopodis pv. citri, pathogens classified as important export quarantine pests (Boureau et al. 2012).

Information on the geographic distribution of a pathogen is important in understanding the disease epidemiology and in development of proper disease management strategies (Retrespo et al. 1999). Since the surveys conducted by Onyango \& Mukunya (1980), the distribution and importance of CBB in Kenya had not been well documented, creating an information gap in the knowledge of the distribution of the disease, until a study similar to the current report was conducted by Chege et al. (2017).

As an element of an integrated management system, the most appropriate method of control of CBB is through the use of resistant varieties. Popular cassava cultivars in Kenya have not been assessed for their reaction to Xanthomonas axonopodis pv. manihotis so that genotypes with a good level of resistance can be recommended to farmers and producers as part of an integrated system for CBB management. Therefore, in this study, selected cassava genotypes that were identified for improvement by other cassava projects were inoculated with CBB strains from various geographic origins within the country and their reaction evaluated.

\section{Materials and Methods}

\subsection{Sample collection}

Leaf samples were collected from plants showing symptoms of CBB in farms within the country. Three to five leaf samples were collected from each farm and composited, constituting one sample for the farm. The collected leaf samples were put in brown envelope bags and put in cool boxes before being transported to the pathology laboratory at the Department of Plant Science and Crop Protection, University of Nairobi. In the laboratory, the leaves were stored at $-20^{\circ} \mathrm{C}$ and later used for bacteria isolation. 


\subsection{Isolation of bacteria and cultural characterization}

Portions measuring about two centimeters square of the diseased cassava leaves with water-soaked angular leaf spots were cut using a sterilized scalpel. The plant tissues were then placed in a petri dish containing $0.5 \%$ sodium hypochlorite for surface sterilization. The surface sterilized tissues were then rinsed three times in sterile distilled water then macerated using a sterile pestle and motor by crushing. The macerate was then dissolved in 10 milliliters of sterile distilled water and transferred to universal bottles, then left to stand for about 30 minutes to allow the bacterial cells to ooze out of the tissues. The solution obtained was then streaked on plates containing nutrient agar and incubated for three days in the laboratory at room temperatures of about $24 \pm 2^{\circ} \mathrm{C}$. The culture characteristics were then recorded to further aid in confirmation of the pathogen identity.

\subsection{Biochemical and physiological tests}

Basic routine biochemical and physiological tests were carried out to ascertain the ability of the bacteria to utilize several substrates and to compare its characteristics with that of other xanthomonads (Table 1).

\subsection{DNA extraction and PCR amplification}

The method described by Cohn et al. (2016) was used in culturing and PCR amplification of the bacteria. The isolates were grown in nutrient agar for 48 hours before extraction. To extract DNA, 50 $\mu$ l of molecular grade water was poured in a safe-lock tube, a medium sized drop of bacteria was then scoped from the petri dish into the safe -lock tube using a sterile wire loop. The mixture was then vortexed well then lysed in water for 10 minutes at $100^{\circ} \mathrm{C}$. The tubes were then put in ice for three minutes then centrifuged for a minute to pellet cell wall material and leave DNA floating in the supernatant. DNA was then amplified using a stock concentration of $10 \times$ PCR buffer, $25 \mathrm{mM} \mathrm{MgCl}, 10 \mathrm{mM}$ DNTPs, $10 \mathrm{mM}$ forward primers, $10 \mathrm{mM}$ reverse primers, Taq DNA, template DNA, and molecular grade water. The PCR program was then set at $94^{\circ} \mathrm{C}$ for 2 minute 32 cycles of $94^{\circ} \mathrm{C}$ for $30 \mathrm{sec}, 58^{\circ} \mathrm{C}$ for $30 \mathrm{sec}$ and $68^{\circ} \mathrm{C}$ for 1 minute, then $68^{\circ} \mathrm{C}$ for $5 \mathrm{~min}$ and infinite holding at $10^{\circ} \mathrm{C}$. The primer sequences were; RB1: GGGATGAGCAGGCAGGGGTTG, RB2: ACTAGTCTGAGGAAATAGCTCCATCAAC.

Table 1. Biochemical and physiological tests carried out to determine the bacterial pathogen causing cassava bacterial blight disease in Kenya.

\begin{tabular}{|c|c|c|}
\hline Test & Importance of the test & Reference \\
\hline Gram stain reaction & $\begin{array}{l}\text { To differentiate bacteria into two categories; gram positive and } \\
\text { gram negative based on the composition of their cell walls }\end{array}$ & Bradbury,1978 \\
\hline Motility test & $\begin{array}{l}\text { To ascertain whether the bacterial cells are motile, indicating } \\
\text { possession of flagella }\end{array}$ & Olutiola et al., 1991 \\
\hline $\begin{array}{l}\text { Gelatin hydrolysis } \\
\text { test }\end{array}$ & To ascertain if the bacteria has enzymes to utilize gelatin & Lelliot et al., 1996 \\
\hline Starch hydrolysis & To ascertain presence of enzymes to utilize starch & Dye et al., 1962 \\
\hline $\begin{array}{l}\text { Fluorescent pigment } \\
\text { production test }\end{array}$ & $\begin{array}{l}\text { To investigate pigment formation by the bacteria when } \\
\text { observed under ultra violet light }\end{array}$ & King et al., 1954 \\
\hline $\begin{array}{l}\text { Reaction to triphenyl- } \\
\text { tetrazolium chloride } \\
\text { (TTC) }\end{array}$ & $\begin{array}{l}\text { To determine the ability of the bacteria to grow under saline } \\
\text { conditions }\end{array}$ & $\begin{array}{l}\text { Louverkovich and } \\
\text { Klement, } 1966\end{array}$ \\
\hline Catalase test & To detect the presence of catalase enzyme in the bacteria & Olutiola et al., 1991 \\
\hline Indole test & $\begin{array}{l}\text { To determine the ability of the bacteria to degrade amino acid } \\
\text { tryptophan and produce indole }\end{array}$ & Olutiola et al., 1991 \\
\hline Oxidase test & To assays for the presence of enzyme cytochrome oxidase & Kovacs, 1956 \\
\hline Casein utilization & $\begin{array}{l}\text { To investigate the presence of exo-enzyme caseinase in } \\
\text { bacterial cells which breaks down milk protein casein }\end{array}$ & $\begin{array}{l}\text { Fahy and Hayward, } \\
1983\end{array}$ \\
\hline $\begin{array}{l}\text { Presence of enzyme } \\
\text { urease }\end{array}$ & $\begin{array}{l}\text { To analyse the capability of the bacteria to hydrolyse urea and } \\
\text { produce ammonia and carbon dioxide }\end{array}$ & $\begin{array}{l}\text { Fahy and Hayward, } \\
1983\end{array}$ \\
\hline $\begin{array}{l}\text { Hydrogen sulphide } \\
\text { production }\end{array}$ & $\begin{array}{l}\text { To determines whether the bacterium is capable of reducing } \\
\text { sulphur containing compounds to sulphides in metabolism }\end{array}$ & Skerman ,1967 \\
\hline
\end{tabular}




\subsection{Cassava variety selection}

Cassava genotypes used in this study were selected from materials obtained at the Biotechnology Centre, Kenya Agricultural Research Organization (KALRO, Kenya) and included Ebwanatareka 1 and Ebwanatareka 2 (which are categorized as highly susceptible to CMD and CBSD but very popular with farmers in the western part of Kenya because of their good cooking qualities), TME 7, TME 14, TME 204 (which are resistant to CMD but highly susceptible to CBSD), and MM96/2480 and MM95/0183 (which are yellow fleshed varieties with medium to high levels of $\beta$-carotene).

\subsection{Isolate selection and inoculum preparation}

Isolates were selected based on the regions where the samples were collected, that is; Western, Nyanza, Central, Eastern and Coast regions. The isolates were grown on nutrient agar in petri dishes and incubated at room temperature for 48 hours. The plates were then aseptically flooded with $1 \mathrm{ml}$ of sterile distilled water. The concentration of the bacteria in $1 \mathrm{ml}$ distilled water was determined using a spectrophotometer, calibrated at OD600 $\mathrm{nm}=0.002$, corresponding to $10^{9}$ colony forming units (CFU). The suspension was then serially diluted to $10^{6} \mathrm{cfu} / \mathrm{ml}$ of bacterial suspension. A drop of tween 20 was added to the bacterial suspension.

\subsection{Plant inoculation}

The leaves of cassava plants were pierced using sterile wooden toothpicks to wound the plant where the second and third leaves were pierced along the midrib. The bacterial suspension was then sprayed on to the injured leaves. The controls were sprayed with sterile distilled water.

For the stem inoculation, sterile wooden toothpicks were dipped into the 48 hour old bacterial culture and used to stab-inoculate the cassava stems between the third and fourth leaves. Sterile wooden toothpicks dipped in sterile distilled water were used to inoculate the controls. The plants were then covered with humidity bags for 24 hours.

\subsection{Symptom assessment}

Symptoms and severity were evaluated from 7 days post inoculation and then every seven days up to 35 days, using a scale of 1 to 5 as described by Wydra et al. (2007) where $1=$ no symptoms, $2=$ angular leaf spotting only, 3 = wilting, angular leaf spotting, leaf blight, defoliation, gum exudates on stems or petioles, 4 = wilting, blighting, defoliation, gum exudation, shoot tip die back, 5 = wilting and blighting, defoliation and gum exudation, abortive lateral shoot formation, stunting, complete die back. The area under the disease progress curve (AUDPC) was calculated on a single plant basis by the trapezoidal integration over the whole observation period as using the formula below (Jorge et al. 2000).

$\mathrm{AUDPC}=\Sigma \mathrm{i}[(\mathrm{DSi}+\mathrm{DSi}-1) \times(\mathrm{ti}-\mathrm{ti}-1)] / 2$

where " $i "=\{7,14,21,28,35\}$ are the days of evaluation, "DS" is the disease score using the above severity scale of 1 to 5 , and " $t$ " represents the number of days post-inoculation.

\section{Results}

3.1 Cassava bacterial blight disease incidence, prevalence and distribution

Leaves showing angular leaf spots and blighting on the leaf lamina were collected (Fig. 1). Out of the 301 farms visited, symptomatic samples were collected from only 224 farms, all of which were positive for growth of bacteria on nutrient agar. The disease incidence, prevalence and severity varied from county to county and based on laboratory assessments the disease was present in 17 of the 20 counties surveyed. The disease was present in most of the cassava growing regions within the country with the exception of Bomet, Baringo, Kiambu and Machakos counties (Fig. 2). 


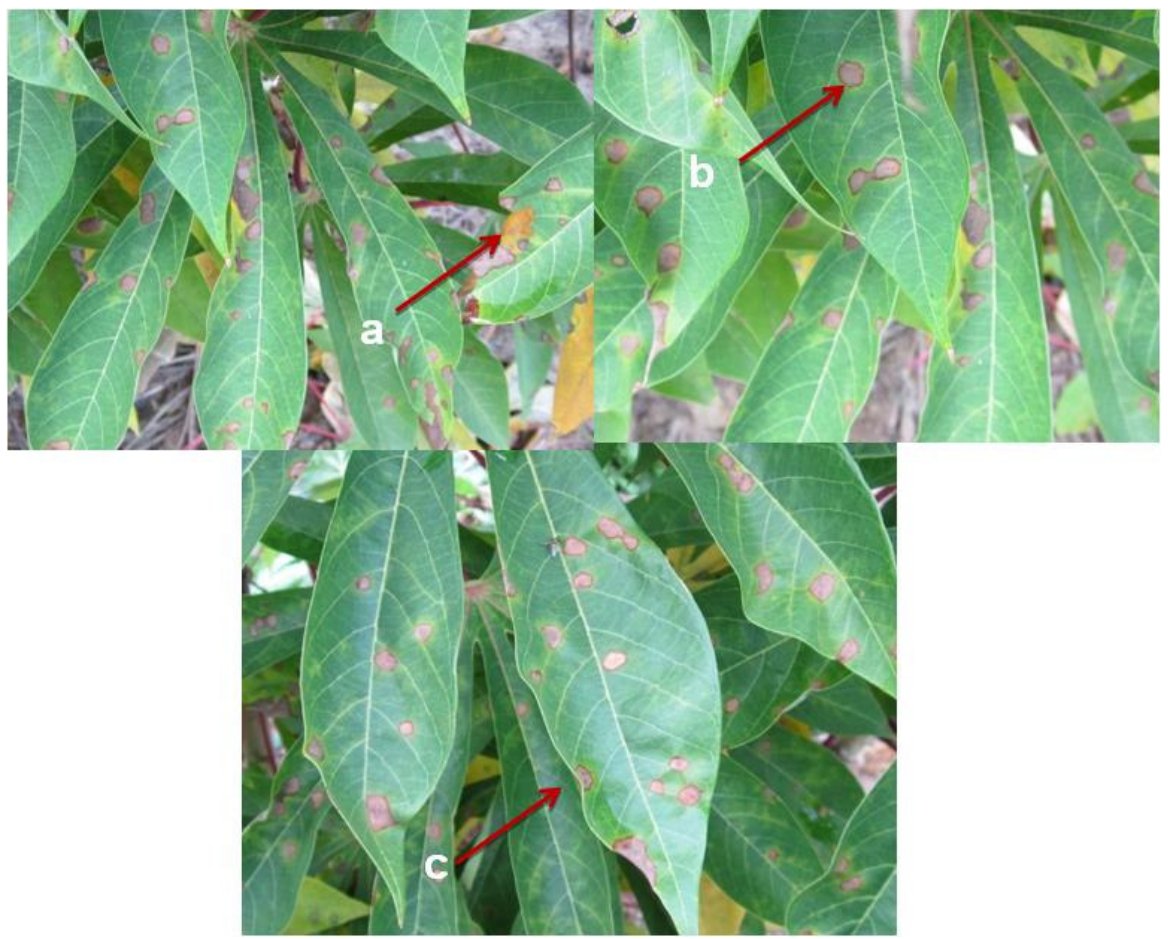

Figure 1. Cassava leaves infected with cassava bacterial blight (CBB) showing blighting and necrosis (a), angular leaf spotting (b) and water soaked lesions at the edges and angular leaf spots (c). The picture was taken in the coastal region of Kenya during disease survey.

\subsection{Bacterial culture characteristics}

Growth of the bacteria on nutrient agar was characterized by colonies that were either cream or yellow in colour. The yellow colonies first appeared cream then slowly turned yellow in the second or third day after isolation. The colour of the colonies was recorded on the fourth day when there were no more changes. The colonies had butter like consistency, and the margins were smooth.

The bacterial cells were motile by means of single polar flagella, utilized starch, hydrolyzed gelatin and did not produce a yellow- green fluorescent pigment under ultraviolet light. The bacterium also grew in media containing triphenyl - tetrazolium chloride salt. These results were consistent with those positive for the causal agent of CBB; Xanthomonas axonopodis pv.manihotis and Xanthomonas axonopodis pv. cassavae. The physiological reactions could however not differentiate the yellow strains from the white strains that cause cassava bacterial blight disease (Data not shown). In the PCR reaction, the bacterium amplified to the primer pair RB1 and RB2 whose target gene was TAL effectors (Fig. 3).

\subsection{Reaction of cassava genotypes to infection by Xanthomonas axonopodis pv. manihotis}

All the genotypes were susceptible to all the isolates but had differential reactions to the different isolates over the time of observation (Table 2). Within the first week, some of the varieties such as TME 204 had a severity average of 1.7 while TME 7 and TME 14 had an average score of 1 indicating no symptoms observed within the first week (Data not shown0. All the plants had an Area Under Disease Progress Curve (AUDPC) of more than 50 (Table 2), further indicating susceptibility. The most significant mean AUDPC was 90.4 recorded in MM95/0183 in reaction to the eastern isolate, and Ebwanatereka1 with 72.1 in reaction to the Central isolate. MM96/2480 had complete wilting and die-back at the end of the five weeks, while TME 7 and TME 14 did not exhibit the same symptoms. 


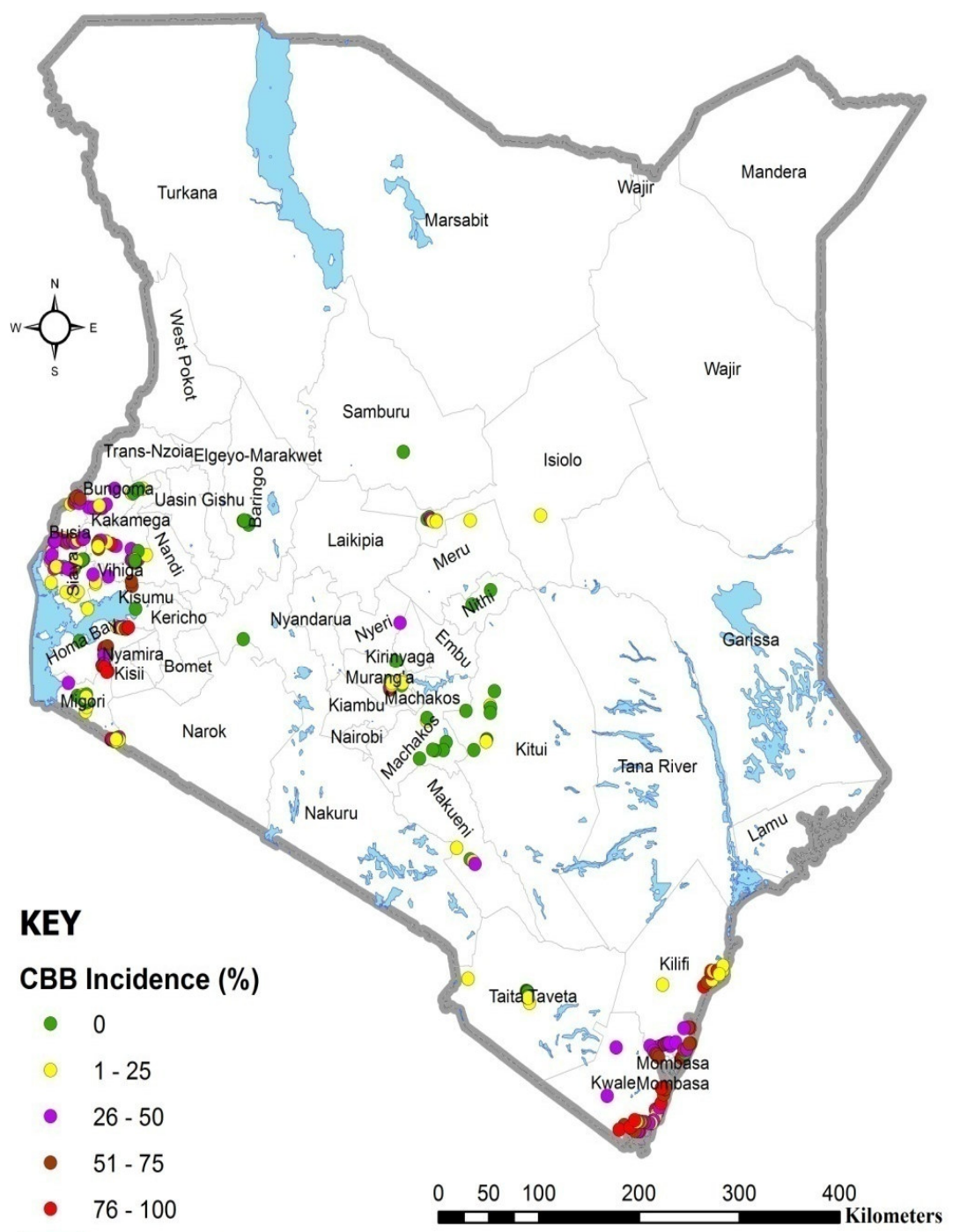

Lakes and Rivers

I... International boundaries

Figure 2. Geographical distribution of cassava bacterial blight in Kenya based on incidence of the disease in the farms visited.

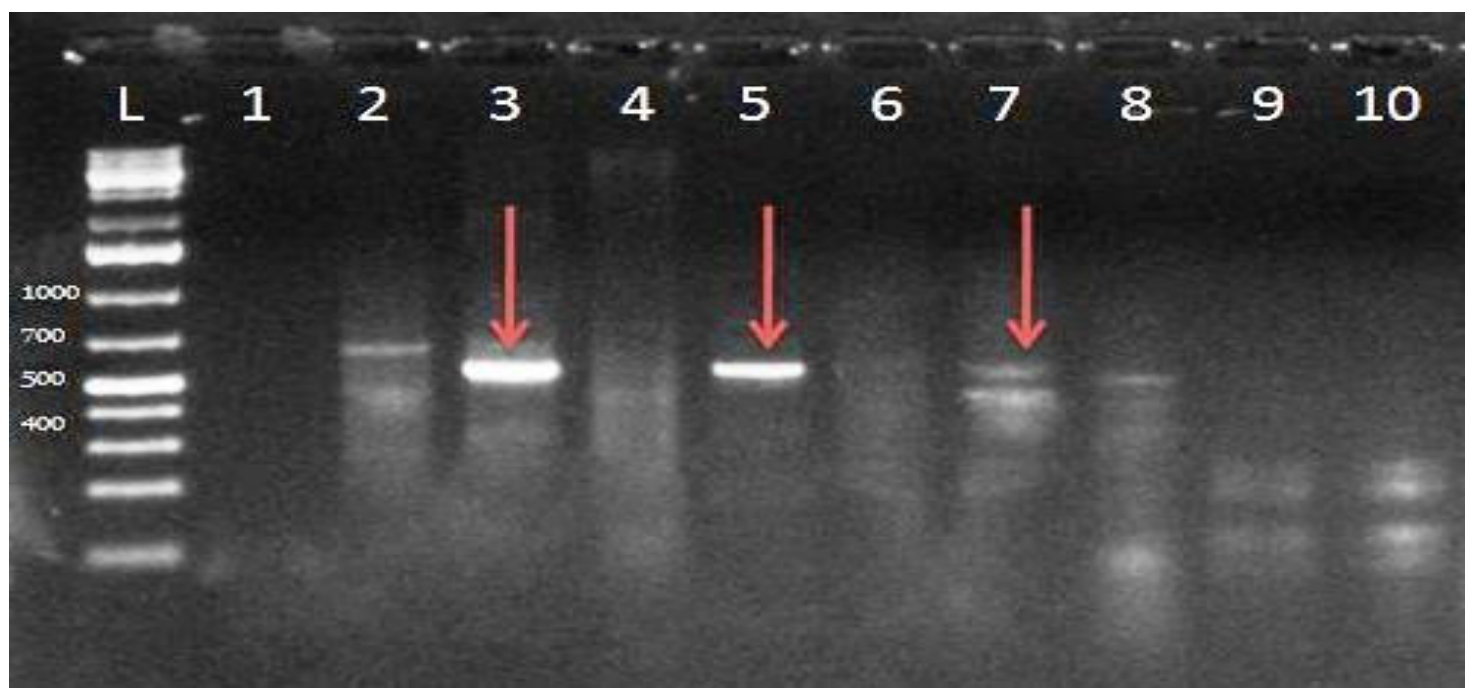

Figure 3. PCR gel pictures showing amplification of DNA for isolates 3, 5, 7 of Xanthomonas axonopodis pv. manihotis using primer set RB1/RB2 at 550 base pairs on $1.2 \%$ agarose gel. 
Table 2. Reaction of seven cassava genotypes to stem-inoculation with five isolates of Xanthomonas axonopodis pv. manihotis under controlled conditions expressed as area under disease progress curve (AUDPC) over 35 days.

\begin{tabular}{|c|c|c|c|c|c|c|c|c|c|}
\hline \multirow[b]{2}{*}{$\begin{array}{l}\text { Isolate } \\
\text { source }\end{array}$} & \multicolumn{9}{|c|}{ Cassava genotype } \\
\hline & Ebwan2 & Ebwan1 & MH95/083 & MM96/2480 & $\begin{array}{l}\text { TME } \\
204 \\
\end{array}$ & $\begin{array}{l}\text { TME } \\
14 \\
\end{array}$ & $\begin{array}{l}\text { TME } \\
7 \\
\end{array}$ & $\begin{array}{l}\text { LSD } \\
(0.05)\end{array}$ & $\begin{array}{l}\text { CV } \\
(\%)\end{array}$ \\
\hline Central & 77.2 & 72.1 & 76.2 & 74.9 & 84.0 & 81.2 & 72.5 & 11.26 & 11.3 \\
\hline Coast & 77.7 & 80.2 & 73.7 & 78.3 & 81.9 & 88.7 & 82.6 & 12.44 & 11.9 \\
\hline Eastern & 77.0 & 79.8 & 90.4 & 74.7 & 77.9 & 78.4 & 72.8 & 9.67 & 9.5 \\
\hline Nyanza & 76.3 & 79.2 & 76.6 & 78.6 & 80.7 & 90.5 & 79.1 & 13.8 & 13.3 \\
\hline Western & 72.1 & 82.0 & 85.3 & 76.3 & 88.2 & 82.0 & 74.6 & 13.02 & 12.6 \\
\hline $\begin{array}{l}\text { LSD } \\
(0.05)\end{array}$ & 11.78 & 8.74 & 14.73 & 5.90 & 12.96 & 15.91 & 13.36 & & \\
\hline CV $(\%)$ & 11.7 & 8.4 & 13.9 & 5.8 & 11.9 & 14.3 & 13.3 & & \\
\hline
\end{tabular}

Analysis done using GENSTAT ${ }^{2} 2012$ analysis of variance (ANOVA) Fishers protected least significant difference test. Means with a common letter are not significantly different. Ebwan2 = Ebwanatareka 2, Ebwan1 = Ebwanatareka 1.

\section{Discussion}

The current study show that CBB is present in most of the important cassava growing counties in Kenya, confirming a report by Chege et al. (2017) which was carried out around the same time, but independent of this study. The disease was present even in areas previously thought to be free of cassava bacterial blight such as the coastal region. According to Onyango \& Mukunya (1982), cassava bacterial blight disease was confined to the western and Nyanza regions of the country. This was mainly attributed to their proximity to the neighboring countries because the disease had earlier been reported in areas across the Tanzania and Uganda borders (Onyango \& Mukunya 1982), hence the possibility of un-quarantined exchange of planting materials (Kwena1992).

Xanthomonas axonopodis pv. manihotis is a gram negative rod shaped bacteria, motile by means of one polar flagella (Ongujobi et al. 2010). It does not have pigmented colonies unlike most of the Xanthomonads when grown in artificial media (Ongujobi et al. 2010). Apart from lack of pigment formation in media, all the other colony and cultural characteristics are similar to those of Xanthomonads (Ongujobi et al. 2010).

The isolates were able to amplify and hence were detected with the primer combination RB1/RB2 whose target gene was the transcription activator like effectors (TAL effectors). TAL effectors are known to promote bacterial growth which in turn results in symptom formation during infection (Cohn et al. 2016). Upon coming into contact with the plant the bacteria delivers the TAL effectors into the plant suppressing host immunity and promoting pathogenesis (Cohn et al. 2016).

Resistance to CBB is considered to be polygenic and additively inherited (Hahn et al., 1979) and is introgressed in cassava from its wild relative Manihot glaziovii (Wydra et al. 2007). The quantitative resistance of cassava to CBB includes several mechanisms such as formation of suberin and tyloses in the xylem vessels limiting disease extension in stems (Kpe'moua et al. 1996), production of latex with high contents of PR-proteins (Cooper et al. 2001), and deposition of phenolic compounds and lignin (Pereira et al. 2000). Resistance mechanisms in the leaves have also been observed and they include formation of cassava cell wall pectins (Wydra et al. 2007), an early drop of infected leaves and reduced multiplication of bacteria in the leaves (Zinsou 2001).

The specificity of interaction between the host and pathogen means that cultivars could be resistant to some strains of Xanthomonas axonopodis pv. manihotis and susceptible to others (Sanchez et al. 1999). It could also mean resistance to leaf inoculation and susceptibility to stem inoculation or the reverse (Zinsou et al. 2005; Wydra et al. 2007). In previous studies, cassava cultivars have shown different reactions to the same strains in different agro ecological zones, further suggesting a genotype $\times$ environment $\times$ strain interaction.

Different varieties had different reactions to the isolates at different assessment periods pointing to possible occurrence of genotype $\times$ isolate interaction. Strain $\times$ genotype interaction has been observed in previous studies where the differential reaction of the strains and the genotypes made the strains to be defined as different pathotypes (Banito et al. 2010; Zinsou et al. 2002, 2004). Specific strain $\times$ genotype interaction at the stem level has also been suggested (Wydra et al. 2004). This phenomenon may explain the slow reaction of TME 7 and TME 14 to the isolates in the first two weeks. Similar observations were reported by Chege et al. (2017) who reported the TME 7 as moderately resistant to CBB. Due to the specificity of interaction of genotypes to strains of CBB, resistant markers specific to African CBB strains have been identified to further enhance the resistance of genotypes to different strains of CBB found within the continent (Restrepo et al. 2000).

All the isolates used in the inoculation were virulent; the difference in the virulence was only observed in the reaction between the Eastern isolate and MM95/0183 which was significantly more susceptible to the isolate compared to the other genotypes as expressed in its AUDPC. The other varieties and isolates had no significant difference in reaction. 


\section{Conclusion}

This study confirms that CBB is widespread in Kenya and that varieties used were all susceptible to CBB isolates obtained within the country. While most of research works being carried out in the country target management of virus diseases in cassava, time and resources should also be devoted to CBB and its management to avoid possible epidemics especially with the changing climatic conditions. Therefore, there is need for the development of cassava varieties that are resistant to the disease. Care should also be taken to limit spread of the disease to areas where the disease does not occur.

\section{Acknowledgements}

We would like to thank the East African Agricultural Productivity Project (EAAPP) for providing financial support The Kenya Agricultural and Livestock Research Organization (KALRO) Biotechnology Research Institute for providing space to carry out the molecular work.

\section{References}

Banito, A., Kpémoua, K.E. \& Wydra, K. (2010), "Screening of cassava genotypes for resistance to bacterial blight using strain x genotype interactions", Journal of Plant Pathology 92,181-186.

Boureau, T., Kerkoud, M., Chhel, F., Hunault, G., Darrasse, A., Brin, C., Durand, A., Hajri, A., Poussier, S., Manceau, C., Lardeux, F., Saubion, F. \& Jacques M. (2012), “A multiplex-PCR assay for identification of the quarantine plant pathogen Xanthomonas axonopodis pv. phaseoli", Journal of Microbiological Methods 92, 42-50.

Chege, M.N., Wamunyokoli, F., Kamau, J. \& Nyaboga, E.N. (2017), "Phenotypic and genotypic diversity of Xanthomonas axonopodis pv. manihotis causing bacterial blight disease of cassava in Kenya", Journal of Applied Biology and Biotechnology 5, 38-44.

Cohn, M., Robert, M., Thomas, L. \& Brian, J. (2016), "Comparison of gene activation by two TAL effectors from Xanthomonas axonopodis pv. manihotis reveals candidate host susceptibility genes in cassava", Molecular Plant Pathology 10, 11-12.

Cooper, R.M., Kemp, B., Day, R., Gomez-Vasquez, R. \& Beeching, J.R. (2001), "Pathogenicity and resistance in Xanthomonas blight of cassava", In: DeBoer S, Ed. Plant Pathogenic Bacteria. Dordrecht, The Netherlands. Kluwer Academic Publishers, p. 319-323.

Hahn, S.K., Terry, E.R., Leuschner, K., Akobundu, I.O., Okali, C. \& Lal, R. (1979), "Cassava improvement in Africa", Field Crops Reserves 2,193-226.

Jorge, V., Fregene, M.A., Duque, M.C., Bonierbale, M.W., Tohme, J \& Verdier, V. (2000), "Genetic mapping of resistance to bacterial blight disease in cassava (Manihot esculenta Crantz)", Theoretical and Applied Genetics 101, 865-872.

Kpe'moua, K., Boher, B., Nicole, M., Calatayud, P. \& Geiger, J.P. (1996), "Cytochemistry of defence responses in cassava infected by Xanthomonas campestris pv. manihotis", Canadian Journal of Microbiology 42, 11311143.

Kwena, P.O. (1992), "Studies on epiphytic population interactions of Xanthomonas campestris pv. manihotis and Xanthomonas campestris pv. cassavae and evaluation of available cassava germplasm against cassava bacterial blight in Kenya", MSc thesis, University of Nairobi, Kenya.

Ojeda, S \& Verdier, V. (2000), "Detecting Xanthomonas axonopodis pv. manihotis in cassava true seeds by nested polymerase chain reaction assay", Canadian Journal of Plant Pathology 22, 241-247.

Ongunjobi, A.A., Fagade, O.E. \& Dixon, A.G. (2010), "Physiological studies on Xanthomonas axonopodis pv manihotis (Xam) strains Isolated in Nigeria", European Journal of Biological Sciences 2, 84-90.

Onyango, R. \& Mukunya, D.M. (1980), "Distribution and importance of Xanthomonas manihotis and Xanthomonas cassavae in East Africa Root crops in Eastern Africa. Proceedings of a workshop held in Kigali, Rwanda, 23-27 Nov. 1980

Pereira, L.F., Goodwin, P.H. \& Erickson, L. (2000), "Peroxidase activity during susceptible and resistant interactions between cassava (Manihot esculenta) and Xanthomonas axonopodis pv. manihotis and Xanthomonas cassavae", Journal of Phytopathology 148, 575-577.

Restrepo, S., Duque, M.C. \& Verdier, V. (2000), "Resistance spectrum of selected Manihot esculenta genotypes under field conditions", Field Crops Research 65, 69-77.

Restrepo, S., Valle, T., Duque, M.C. \& Verdier, V. (1999), “Assessing genetic variability among Brazilian isolates of Xanthomonas axonopodis pv. manihotis through RFLP and AFLP analyses", Canadian Journal of Microbiology 45, 754-817.

Rowan, M.G., Blagbrough, I.S., Bayoumi, S.L. \& Beeching, J.R. (2010), "Cassava: An appraisal of its phytochemistry and its biotechnological prospects", Phytochemistry 71, 1940-1951.

Sãnchez, G., Restrepo, S., Duque, M.C., Bonierbale. M. \& Verdier, V. (1999), “AFLP assessment of genetic variability in cassava accessions (Manihot esculenta) resistant and susceptible to the cassava bacterial blight 
(CBB)", Genome 42, 163-172.

Tonukari, N.J. (2004), "Cassava and the future of starch", Electronic Journal of Biotechnology 7, 5-8.

Trujillo, C.A., Ochoa, J.C., Mideros, M.F., Restrepo, S., Lòpez. C. \& Bernal, A. (2014), “A complex population structure of the cassava pathogen Xanthomonas axonopodis pv. manihotisin recent years in the Caribbean region of Colombia" Microbial Ecology 68, 155-167.

Wydra, K., Zinsou, V., Jorge, V \& Verdier, V. (2004), "Identification of pathotypes of Xanthomonas axonopodis pv. manihotisin Africa and detection of specific quantitative trait loci (QTL) for resistance to cassava bacterial blight”, Journal of Phytopathology 94, 1084 - 1093.

Wydra, K.A., Banito, K. \& Kpémoua E. (2007), "Characterization of resistance of cassava genotypes to bacterial blight by evaluation of symptom types in different ecozones", Euphytica 155, 337-348.

Zinsou, V., Wydra, K., Ahohuendo, B. \& Hau B. (2004), "Effect of Soil Amendments, Intercropping and Planting Time in Combination on the Severity of Cassava Bacterial Blight and Yield in Two Ecozones of West Africa", Plant Pathology 53, 585-595.

Zinsou, V., Wydra, K., Ahohuendo, B. and Hau, B. (2005), "Genotype $\times$ environment interactions in symptom development and yield of cassava genotypes with artificial and natural cassava bacterial blight infections", European Journal of Plant Pathology 111, 217-233.

Zinsou, V., Wydra, K., Ahohuendo, B., Jorge, V. \& Verdier, V. (2002), "Evaluation of cassava genotypes, including individuals of their genome mapping population, for resistance against bacterial blight. 'New Aspects of Resistance Research on Cultivated Plants' Bacterial Diseases". Beitr Zu“ chtungsforschung BAZ 8, 31-35.

Zinsou, V. (2001), "Studies on the expression of resistance of cassava genotypes including individuals of the mapping population to cassava bacterial blight", MSc thesis, University of Go" ttingen, Germany 17-233. 